\title{
The Uses of Social Media Sites in the Shopping Process from the Point of View of users of E-shopping Platforms and the Gratifications Achieved from Them
}

\author{
Assist. Prof. Dr. Ethar Tareq Khaleel
}

\author{
Al-Iraqia University, College of Media, Iraq \\ Received: 12 May 2021; Received in revised form: 04 Jun 2021; Accepted: 15 Jun 2021 \\ (C)2021 The Author(s). Published by TheShillonga. This is an open access article under the CC BY license \\ (https://creativecommons.org/licenses/by/4.0/)
}

\begin{abstract}
Social media sites formed a new framework for the relationship between sales centers and the customer and transformed the relationship between them into an electronic relationship, but it is based on constructive and fruitful interaction between the two parties, and thus produced a new form of communication that did not exist before the popularity of these sites.

As soon as those in charge of shopping centers and sales outlets realized that these sites would lead them to a wide and interactive audience, as they would lead the public to interact with them while sitting at their home or workplace, he started racing to create an account for him on one or more of those platforms.
\end{abstract}

Each of the parties to the sales and shopping process has his arguments and reasons that lead him to use these platforms, especially since we live in the midst of a world of complexity in various aspects of life.

This research has shed light on the extent of the public's use of these platforms in the shopping process as a new type of relationship between shopping outlets and the public who visit those outlets, and the most important findings of the research are the following:

1- The Baghdad public prefers to use social media sites in the shopping process to shorten time and effort due to the inability to go to the markets sometimes.

2- The emergence of the priority of using Facebook and Instagram sites in the shopping process, due to its wide spread in the city of Baghdad.

3- The Baghdad public's reliance on social media sites in acquiring clothes, due to the large number of promotional advertisements about them.

4- Friends usually advise their peers to shop through social media sites, and this indicates a kind of viral marketing of the commodity.

Keywords-Uses and gratifications, social media sites and e-shopping.

\section{INTRODUCTION}

The contemporary world has witnessed a set of changes in the field of communication and information technology, which made the world resemble a small village where information is transmitted to all parts of the globe in the least fraction of a second. There is no doubt that these changes have a direct impact on the various fields of cultural, economic, intellectual and social life. Therefore, the individuals and institutions that make up the society, which prompted them to accept this development and adapt to it in order to benefit from the advantages it offers in all different fields.

Social media sites are one of the modern technical tools and media that give individuals a period of presence on the Internet, allowing them to express their opinions, trends and ideas, as well as help them in marketing their products. The most important sites and tourism components of the country and the role of participants in these networks to transfer their experiences and knowledge about the destinations and places they visited to create a realistic and 
reliable atmosphere for those potential tourists. Therefore, the research has been written in order to highlight the importance of social media, especially Facebook, as an essential element in modern marketing.

This research is divided into significant sections, an introduction and a conclusion, where the first topic dealt with the methodological framework of the research in terms of the research problem and its questions, the importance of the research and its objectives, the limits of the research, the type of research and its methodology, the research tools, the test form and the method of data collection, the research community and its sample. This research provides a full explanation of the methodological steps adopted by the research.

The second topic, it dealt with the uses of social media sites in the shopping process from the point of view of the users of e-marketing platforms and the gratifications achieved from them.

The third topic came to include the field study of the research, which identified the importance of using social media sites in the shopping process from the point of view of the users of e-marketing platforms and the gratifications achieved from them.

\section{METHODOLOGICAL FRAMEWORK}

\section{First: the research problem:}

The research problem is defined as an ambiguous situation that excites the researcher and generates a desire to reveal this ambiguity. So, to determine the scientific problem, there are important steps for this determination, which are represented, according to the opinion of experts, such as Al-Mashhadani (2019) and as follows:

1- A sense of the scientific problem.

2- Analysis of the scientific problem.

3- Evaluation of the scientific problem.(p.65)

Our contemporary reality has witnessed a wide development in the spread of the Internet at all levels, as a result of this development of communication technology, many concepts and roles have changed. To achieve communication between individuals and groups. However, websites, personal blogs and chat networks appeared that changed the content and form of new media and social networking sites of great importance in the process of shopping and shopping via websites and this helped companies and organizations to increase their profits and sales as well as satisfy the needs of the disordered masses from the process of shopping via the Internet, and a problem is identified Search the following questions:
1- What is the extent of the use of social media sites in the shopping process from the point of view of users of eshopping platforms and the gratifications achieved from them?

2- What are the most prominent sites used by the public in the shopping process?

3 - What are the most important problems facing this relationship?

4 - What are the most prominent goods that customers buy from these platforms?

5 - Can a viral marketing process arise for goods offered electronically?

\section{Second: The importance of research:}

The research acquires its scientific importance by facilitating access to the collection of the various goods available in the electronic shopping platforms that provide the satisfaction of the different needs of the public in the shortest time and least effort, as well as addressing the problem of the difficulty of mass access to the direct selling center, and given the huge numbers of individuals who use social media sites in All their activities and interactions can be said that it has become an effective marketing tool in order to reach consumers and achieve gratification from them.

\section{Third: Research objectives:}

The research objectives focus on the following points:

1- To identify the extent to which social networking sites are used in the shopping process from the point of view of the users of electronic shopping platforms.

2- Knowing the most important social media site that individuals use for online shopping.

3- Knowing the most prominent goods that customers buy from those platforms.

4- Access to the possibility of creating a viral marketing process for the goods offered electronically.

5- To identify the most important problems facing the shopping process.

\section{Fourth: Research Methodology:}

The research method means the law, principle, or rule that allows any equation for scientific study and in any field. any scientific fact. This research is a descriptive research, as it used the survey method, which is one of the basic methods in descriptive research, being the most appropriate for this type of studies, percentages, and statistical data.

Fifth: The research community and its sample:

Society is represented in two ways: 
1- The research community in general represents all the individuals who are related to the characteristics and qualities that are suitable to be the focus of the researcher's interest.

2- The research sample, which is the category that represents the research community or the research audience, i.e. the apparent vocabulary studied by the researcher, individuals, people or things that are the subject of the research problem. The research sample was determined by an unintentional random sample. (Tabaja,2011,p.196)

\section{Sixth: Research areas:}

1- Temporal domain: The temporal domain is determined by the research by the period in which it is conducted and a questionnaire was organized, which extends for the period from $(1 / 1 / 2020)$ to $(2 / 2 / 2020)$.

2- Spatial domain: The spatial domain has been determined in the province of Baghdad.

3- The human Domain: the human sphere is determined by the audience of Baghdad, the capital of Iraq.

\section{Seventh: The research tool:}

The researchers used the questionnaire as a main tool for collecting data from the respondents, through a form that includes questions sent by mail or delivered to the respondents who record their answers themselves, as (200) questionnaire forms were distributed, collected and analyzed in a scientific manner in line with the requirements of the research.

\section{Eighth: The integrity test:}

The integrity of the tool is intended to verify the validity of the measurement method or the tool of topics or phenomena that the researcher wants to analyze and draw the results obtained and then evaluate them. (Alyan,2000,p.42)

\section{Content authenticity (apparent honesty):}

Abdel Hamid (2009) identified several types of honesty, including apparent validity, prediction validity, agreement validity, and construction validity. (p.225)

The researcher presented the questionnaire to a group of experts and specialists in the field of scientific research and media to benefit from their scientific observations and then take it to evaluate it in its final form.

The reliability rate has been used, according to the following equation:

Number of paragraphs agreed / total of paragraphs x 100 the number of paragraphs agreed upon

$$
\text { X } 100=\text { Reliability }
$$

total paragraphs
66 $X 100=94.2$

70

\section{THEORETICAL FRAMEWORK FOR RESEARCH}

\subsection{Communication sites, marketing, uses and gratification theory}

First: Social media (concept, tools, applications)

The concept and definition of social media sites:

It is a set of programs and tools on the Internet with the public of users to exchange content, opinions, ideas, experiences and views, and works to facilitate conversations and interactions over the Internet.

It was also defined as:

Sites or applications that begin with the user creating an account on one of the social media sites, Facebook, Twitter, etc. within the scope of the World Wide Web, which allows him to build a personal database, a launch platform, an electronic presence, and a virtual personality. To publish data, comments, documents, messages, photos and videos, and then start the stage of networking and sharing with others by acquiring friends, forming groups and exchanging comments, opinions and media materials with them, and this process of communication takes place in an instant.

(Abdul Razzaq,2013,p.39)

It was also defined as:
An electronic social structure that is made by individuals, groups or institutions, and the basic formative part, such as one individual is called 
the node, so that this node is connected to different types of relationships such as encouraging a particular team, belonging to a company, or holding a nationality for a country. What is in this world, and these relationships may reach a more profound degree, such as the nature of the social status, beliefs, or class to which the person belongs, social networks are interactive, allowing users to communicate at any time they want and anywhere in the world. They appeared on the Internet a few years ago and changed the concept of communication and rapprochement between humans.

(Sabti,2018,54)

\subsection{Social Media sites (Facebook, Twitter, Instagram, YouTube):}

Communication sites are characterized by the ability to challenge the existing conditions and express freely, as they have the freedom to be independent from the political and social system, and they are able to create public interest in a general and motivate them to form their opinion.

It was later revealed that social networks excel in forming public opinions about the Arab revolutions, and this is the result of these means allowing the public to express their opinion freely while achieving participation more effectively.

In addition, without a doubt, the image is not completely rosy. There are false news, fabricated pictures, and people moving under fake names. However, banning these sites is not a solution to dealing with these technologies, because activists will succeed in accessing alternative means, so the best option is social control and subjectivity.

\subsection{The most important applications of social networking sites:}

\section{1 - Facebook:}

Al-Bayati (2014) mentions that Facebook was created by a student at Harvard University called Mark with the aim of finding a way to communicate between current students and graduates of his university. To participate in it, in addition to that Facebook enables individuals to meet new friends and contact old friends and helps individuals exchange information, files, photos, videos and instant chats. (p.281)

Facebook contributes to providing the appropriate ground and general atmosphere to prepare public opinion to express itself through demonstrations and gatherings, as well as a means for coordinating positions, setting goals, directing the public and organizing its movement in the demonstrations. In 2016, the Facebook administration added the translation feature from the English language and Arabic or any other language, in addition to the feature of direct communication through Facebook and more than fifty people at the same time.

Facebook in Iraq:

Facebook is the most popular social network in the Arab countries. In Iraq, statistics in the year 2020 indicate that there are approximately 30 million "active and interactive" users on the Internet, an increase of 11 million users over last year. Social media this year reached 21 million active users, an increase of 1.9 million over the last statistic of Hootsuite and We are social, which specialize in this field, where the number of Facebook users reached 17 million active users.

The number of subscriber pages on social networking sites in Iraq has increased significantly, after the political events in the Arab world, and with it the general trend to create special pages on Facebook, whether for individuals from citizens or for all Iraqi media institutions, and statistics indicated that there are more than one million of pages on Facebook inside and outside Iraq from expatriates.

There is a large media presence on the Facebook network, which is the most preferred by people because it creates a state of individual stardom with its capabilities in adding pictures, promoting links and videos, and creating a state of admiration for the blogged cases.

\subsection{Features of Facebook:}

Facebook as a social network is characterized by a number of features that allow users to communicate with each other. According to Al-Karkhi (2016), the most important of Facebook Features are the following:

1 - Characteristics of wall and mailbox messages: This feature is considered an e-mail development and has become relied upon by huge numbers of users. Or it is especially seen on the mailbox.

2 - Conversation: or what is known as messaging and chat services, it allows the exchange of electronic messages between users to achieve more interaction. 
3 - Poke feature: It allows sending a virtual poke to draw attention to each other, which is a notification notifying the user that a friend is welcoming him.

4- Photo feature: enables users to upload album and photos to the site.

5 - Status feature: allows the ability to inform friends of their whereabouts and what they are doing at the moment.

6 - The feature of notes or comments: It was added as a form of blogging and allows adding references, images and comments to written texts, as it became possible to import blogs from blogging sites and services to Facebook.

7 - News Feed: After the user opened an account to find his private page, users now read a summary of their friends' activity on Facebook, which leads to more communication and networking for which the networks were originally established.

8 - Photos and videos: They are one of the most popular Facebook applications with the ability to add tags and comments, in addition to creating live broadcast videos.

9 - Events, groups, and networks: It is one of the methods of electronic organization and mobilization so that users gather geographically, qualitatively and functionally, conduct discussions and organize political and social events.

10 - Developers platform: In May 2007, the developers platform was launched to allow users to develop new applications and improve old applications to open the way for thousands of new applications that can be employed for any purpose.(p.81)

\section{2 - Twitter:}

Twitter was established by three researchers Jack Drossi, Evan Williams and Beeston in 2006. Twitter was initially intended for journalistic purposes, but the use of it by celebrities turned into its use to convey the news of their daily lives and interests. (Al-Tamimi,2015,70)

The researcher adds that the number of letters was increased in mid-2018 to 280 letters for all tweeters globally.

Shafiq (2010) believes that Twitter is defined as a service that helps friends, family members, and co-workers to communicate and maintain contact with each other by exchanging quick and usual answers to one simple question, what are you doing now?. The site appeared as a research development project conducted by the American company Odeo in San Francisco and then the company officially launched it for users in general, and then the site began to spread as a new service on the scene in 2007 in terms of providing micro-blogging.(p.214)
Twitter is one of the most famous social networks and its means, and it provides a micro-blogging service that allows its users to send "tweets" that would impress other tweeters, directly through the site or by sending an SMS, instant messaging programs or applications it provides. Developers such as Facebook, twitbrid or twitter fox and these updates appear on the user's page and friends can read them directly from their home page or visit the user's profile, and responses can also be received by e-mail and by text messages (SMS). However, some statistics indicate that there are (1.28 million) users of Twitter in Iraq.

\section{3- Instagram:}

It is one of the free programs that works on smart phones. It is based on sharing pictures through the program and social networking sites such as Twitter, Facebook, Flickr. It is characterized by the hashtag \# feature to show that the occasion is valuable and enables friends to participate, and one of its features is the ability to modify images and add Influences on it through various tools, and Instagram has recently become very popular and has become a strong competitor to other networking sites. Instagram helps to get closer to the masses by sharing with them photos and short videos and allowing them to express themselves freely and make suggestions through comments on posts. Statistics indicated that there are 9.50 million active Instagram users in Iraq

\section{4- YouTube:}

YouTube was founded in 2005 by three PayPal employees Chadherley, Steve Chen, and Jawed Karim in the United States of America. Comment and like on the clips they watch.

The site uses Adobe Flash technology to display animated clips, and the site's content varies between movie clips, TV clips, music clips, video produced by amateurs, and others. There is no censorship over what is broadcast or attached to YouTube, and therefore it contains clips that may It does not agree with the cultures and values of all peoples, as the site contains wretched and fat. From a media point of view, all the bets of attracting the masses are directed in favor of the audio-visual message at the same time, because the effect of sound and image accompanied by movement exceeds the effects of sound only or image only.

The statistics of download, upload and viewing rates on YouTube are somewhat numerous due to the free service that the site provides for hosting and watching videos. It is used in education and entertainment, as well as in advertisements, personal conversations and social discussions. It is also used for acquaintance and the search for fame. 


\section{4 - Blogs:}

Blogs appeared in 1997 and John Barger was the first to coin this term, but blogs did not spread on the Internet until after 1999, when the hosting service began to allow beneficiaries to create their own blogs relatively quickly and easily, and it is one of the forms of electronic interactive system The most important, as it is a personal website on the Internet that includes opinions and positions on various issues, and it is an Internet application that works through the content management system of contents, and it is a page on the Internet on which the posts appear dated and arranged in ascending order.

Blogs allow in their contents all access, viewing and participation to a specific audience of Internet users who interacts with information, written opinions and all published materials, whether with views or written comments, and these are called blog readers, and after the massive expansion and spread of blogs, the purposes were multiplied and the ways expanded. Diversity has increased in these blogs, so we find scientific and other blogs for technology, computer science, the Internet, music...etc.

Blogs enable the user to publish what he wants on the Internet with the possibility of saving what he publishes in a way that he can refer to through a simple interface that is almost similar to the interfaces of e-mail sites, and relieves the user of the burden of technical complications usually associated with this type of publication. This engine was deduced from the growth rate of these sites that far exceeds the rest of the types of Internet sites, and statistics in 2006, indicate that there are more than 50 million blogs in the world.

\section{Second: Marketing, its functions and activities:}

Marketing is the main key that achieves the goals of any organization, as it includes identifying the needs of target markets, in addition to obtaining a more effective guarantee in the face of competitors, and that e-marketing standards in any company or organization require a technical infrastructure, as well as a set of tools Which helps him to communicate directly and effectively with the target segments, such as e-mail, pages, social networking sites, etc., and that the wide spread witnessed at the present time in the means of social communication constituted a major shift for communication and information exchange between individuals, as we are currently seeing a state of addiction and the increasing craving for it by all segments of society in all its sectors and categories, and what most confirms this is the growing efforts of companies to develop practical strategies to enter this social network, especially by the public relations sector, for permanent communication With its customers, listening to their opinions and requirements, and focusing on exchanging and sharing information with the basic segments of society by adopting and using the latest in social communication channels.

Marketing is defined as a set of integrated activities and works aimed at providing a good or service to the customer in the required quantities and specifications, at the right time and place, and at the lowest possible cost.

The British Institute of Marketing defines it as

An administrative process
that is responsible for
defining and achieving
customers' desires and
their satisfaction by
providing them with
benefit in light of their
requirements. Modern
marketing, and marketing
needs public relations
efforts in order to create
what is known as a
harmonious relationship.

(Shaiba,2016,42)

\section{Marketing Activities:}

Marketing includes all of the following activities:

1. Identifying the needs and desires of the target audience through marketing research and marketing feasibility studies, before embarking on the production or opening of the shop

2. Take all decisions with respect to the marketing mix.

3. Customer Care: This includes taking care of the consumer during the sales process and after the sales process by following up and solving his problems and hearing his complaints.

4. Attention to customer retention because attracting new customers is more costly than retaining existing customers. As an example of the importance of retaining existing customers, in a study of an airline, it became clear that $50 \%$ of customers who faced problems with this company and did not have the opportunity to complain became customers of competing companies, while $87 \%$ of those who had the opportunity to complain and their complaint was resolved did not leak to the competing companies.

5. All departments and employees of the project must target consumer satisfaction and focus on the customer, which has become of special and strategic importance in light of the transition from the concept of the market to the concept of the buyers market. 
Marketing activities precede the production process or the opening of the shop, and it is also considered one of the most important activities that follow productivity

\section{Marketing Functions:}

There are several functions of marketing, the most important of which are the following:

1. Purchasing function includes research and evaluation of suitable goods and services

2. The selling function includes promotion, personal selling, advertising and publicity.

3. The transport function includes moving goods from one place to another which means physical transport.

4. The function of storage includes keeping the goods for the time they are needed from the market.

5. The function of classifying goods according to their quality and size, which facilitates the purchase process by the consumer.

6. The financing function, which includes providing financial and material support and credit for production, transportation, storage, classification, selling, and promotion.

\section{Internet Marketing}

What is e-marketing, its importance and the difference between it and regular marketing?

Before starting to address the concept of Internet marketing, it should be noted that the concept of Internet marketing does not differ from the traditional concept of marketing, except with regard to the means of communication. How Internet marketing depends on the web as a means of communication that is faster and less expensive, due to the low cost of Internet marketing, compared to traditional marketing and its ability to expand markets and increase sales, it launched at an amazing speed across the world. So, advice to potential customers. Studies confirm that online shopping leads to the expansion of markets and an increase in the market share of companies by $3.22 \%$ due to the global spread.

The nature of e-marketing:

The importance of e-marketing has increased during the recent period, especially after the development that was accompanied by the Internet and the openness and progress in technology and information, which led to the development and expansion of the uses of the Internet by the public in the search for various needs represented in shopping in all its forms, whether goods or services and satisfying those Needs by searching in SAT websites on the Internet or through social media sites, such as Facebook and Instagram.
The nature of e-marketing can be summarized through a set of points that clarify this matter as follows:

1. The development of the Internet through three stages produced many opportunities, including commercial uses, especially after the nineties of the last century.

2. E-marketing is part of electronic business, which in turn, together with e-government, forms what is known as emanagement.

3. E-marketing is the process of creating and maintaining customer relationships through

4. Direct electronic activities with the aim of facilitating the exchange of ideas, products and services that achieve the objectives of both parties.

5. The development of e-marketing has provided real opportunities for marketing men, producing organizations and distribution facilities, the most important of which is the possibility of reaching the largest possible number of customers at the lowest costs and communicating with them directly.

6. The electronic marketing mix differs from the traditional marketing mix by focusing a lot on communication technology, customer relations and discrimination.

\section{The importance of e-marketing:}

1. Companies' reliance on the Internet for marketing allows them to display their products and services around the world without interruption throughout the hours of the day and days of the year, which provides these companies with a greater opportunity to make profits, in addition to reaching more customers.

2. Reducing corporate expenses, as the process of preparing and maintaining e-commerce websites on the web is more economic than building retail markets or maintaining offices, and companies do not need to spend big on promotional matters, as there are online databases that keep the history of sales operations in the company and the names of customers.

3. Effective communication with partners and customers, as e-marketing covers distances and crosses borders, which provides an effective way to exchange information with partners, and also provides a good opportunity for companies to benefit from the goods and services provided by other companies, i.e. suppliers, in the so-called electronic commerce from business to business.

7. The difference between Internet marketing and traditional marketing

The most important differences between Internet marketing and traditional marketing are: 
1. Online shopping allows knowledge of the institution and its products, services and offers at the global level without the cost of your face, while traditional marketing requires an expensive effort to reach foreign markets.

2. The institution's dealings via the Internet allows it to communicate with very large numbers of visitors on the company's website, in addition to its constant presence on social networks that goes beyond local and regional frameworks to reach global frameworks.

3. Internet marketing depends on information technology, allowing the exchange of information and satisfying the needs of buyers.

4. The Internet market is not subject to the restrictions of time, place and costs as in traditional markets.

5. Internet marketing contributes to opening the way for everyone to market their goods or experiences without distinguishing between an institution with huge capital and an ordinary individual.

6. E-marketing mechanisms and methods are easy to implement compared to traditional marketing mechanisms.

7. Internet marketing is environmentally friendly, as it does not require cutting down trees or polluting the environment and the use of fuels, as is the case in traditional marketing.

8. The use of software techniques accompanying the Internet marketing environment allows the organization to simply evaluate and measure the extent of success in any advertising campaign and identify weaknesses and strengths in it, as well as the possibility of directing or determining the geographical distribution of the target segments in these campaigns and other goals that seem difficult to achieve in traditional marketing.

\section{Use the Internet as a distribution channel:}

The nature of traditional distribution channels has changed with the emergence of electronic marketing and we are talking about electronic distribution channels, as the Internet has become:

1. The market space that enables access to the customer.

2. The emergence of the Internet as a new distribution channel has led to two important developments. On the one hand, many electronic intermediaries have appeared that help bring the product closer to the consumer, and on the other hand, many traditional distributors have been eliminated on the condition that the jobs they perform are transferred either to producers or to electronic intermediaries.

3. With regard to physical distribution in light of electronic marketing, part of it remained the same, which is related to the distribution of physical goods, but the distribution of services and some private goods are now distributed through the Internet, and the small parcel delivery sector has developed with the development of electronic commerce.

4. E-stores are created and managed in the form of small, simple or large and complex websites, making the construction costs range from hundreds to millions of dollars. These stores deal in their various forms in marketing goods and services electronically, whether the distribution is local or international.

Third: The theory of uses and gratifications, such concept, elements, assumptions, and objectives:

\section{The concept of uses and gratifications theory}

The theory of uses and gratifications is one of the most important modern communication theories that explain the role that the public plays in the process of communication with the media. The needs and motives with the driving factors for communication in particular are those needs and motives that the individual expects to be satisfied or fulfilled by others to achieve adaptation to the environment.

The concept of the theory was launched through the public's exposure to the media product to satisfy certain latent desires in response to the motives of individual needs.

This theory confirms the effectiveness of the recipient, as he is constantly deciding what he wants to take from the media instead of allowing the media to direct him the direction he wants. The effect of his means on him, and therefore this theory seeks to answer an important question related to the reasons for the public's choice of a certain media content over the other.

Within the framework of studies on the use of the media and exposure to it from various groups, these studies focused on the reasons for this exposure in an attempt to link these causes and uses with the classification of use in categories indicating its intensity or intensity. These reasons were formulated in several frameworks, the most important of which was the framework psychological motives that motivate an individual to meet certain needs at a particular time.

The selective behavior is the selection of the recipient for what satisfies his needs, not only from the communication processes in general, but his selection of what he wants from the single media process by paying attention to what he wants to realize and remembering what he wants and doing what he wants as a result of his selection, and that this behavior, which was caused by a certain confusion or ineffectiveness of the media The mass is in fact one of the factors that fall between the stimulus and the response and 
determine the nature of the effect. This means that the selective activity and interpretation of the recipient, the sociological foundation on the structure of the individual's need, some researchers believe that this theory is a simplified version of the theory of individual differences.

\subsection{Elements of uses and gratifications theory}

The uses and gratifications theory consists of several elements as follows:

1. The recipient is an active element, which means that it is an important part of the use of media and communication, as it is assumed that he is the target, and thus, the recipient's use of media and communication can be interpreted as a response from him to the need that he senses, and the recipient expects to obtain through his behavior in using the means of information and communication are some of the forms of satisfying his needs, such as the need for relaxation and entertainment.

2. The initiative in linking the satisfaction of needs by choosing the appropriate means, but it is subject to the recipient himself in the process of mass communication, and this model sees that people are addicted to the media and communication to meet their needs rather than being an influence factor in them.

3. The new media compete with other sources to satisfy the needs of the public, such as playing games, personal visits, social meetings and trips. So, the means of communication must take into account the existence of traditional alternatives that compete with them in satisfying the needs.

4. Ensuring that the audience is the one who chooses the messages and content that satisfies their needs. Individuals are the ones who use the means of communication and not the other way around.

5. From the methodological point of view, a lot of data about the goals of using the means of mass communication can be deduced from information we derive from the individuals themselves, because people have selfawareness and the ability to efficiently record their interests and motives or at least their observations when they ask about them in an easy and understandable form.

6. Issuing value judgments about the cultural importance of mass communication its impact on mass culture, the formation of awareness among the public must be postponed between the formation of the audience's orientations in the subject of exploration through themselves.

\subsection{Assumptions of uses and gratifications theory}

Among the most important assumptions that the uses and gratifications theory seeks to measure are:
1. Members of the public are active participants in the process of mass communication and use the means of communication to achieve intended goals that meet their expectations.

2. The prevailing cultural norms can be inferred from the public's use of the means of communication and not only through the content of messages.

3. Members of the public choose the media material that they see as satisfying their needs.

4. The use of means of communication expresses the needs that members of the public are aware of, and this is controlled by the factors of individual differences, social interaction and the diversity of needs according to different individuals.

5. The uses and gratifications theory assumes that people are aware of their needs and are able to verbalize them when asked.

\subsection{The objectives of the uses and gratifications theory}

The uses and gratifications perspective achieves the following main objectives:

1. Seeking to discover how individuals use the means of communication, in view of the active public who can choose and use the means that satisfy their needs and expectations.

2. Explain the motives for exposure to a particular means of communication and the interaction that occurs as a result of this exposure.

3. Emphasis on the results of using the means of communication in order to understand the process of mass communication.

4. Revealing the required gratifications that the individual seeks to satisfy through his use of the means of communication and the (achieved gratifications behind this use.

5. Detecting the interrelationships between the motives for use and the patterns of exposure to the means of communication and the resulting gratifications.

\section{Case study}

10.1 Descriptive analysis of the respondents' answers about the uses of social networking sites in the shopping process from the point of view of the users of electronic shopping platforms and the gratifications achieved from it

In this topic, the procedures of descriptive analysis of the answers of the respondents from the audience of the city of Baghdad have been taken place, which numbered (200) respondents, distributed over the various regions of the capital, in the first section of it reviewing the statistical 
analysis of the demographic variables of their own in terms of gender, age, school stage and type of study. Then, in the second section, we address the respondents' answers to their exposure questions, which include (14) questions.

\section{First: Descriptive analysis of the demographic} variables of the respondents:

\section{1- By gender:}

It is shown from Table No. (1) that the respondents, who numbered (200) from the public of the city of Baghdad, were distributed by type to (122) respondents from females with a percentage of $(61.0 \%)$, and (78) respondents from males with a percentage of $(39.0 \%)$, and they were Preference is given to females, who ranked first.

This indicates that the process of shopping through these platforms attracts more interaction among females than males, and this is closer to the reality of Iraqi society and the East in general, which places a kind of social determinants on the movement of women.

Table.1: Shows the gender category of the respondents

\begin{tabular}{|c|c|c|}
\hline Gender & Repetition & Percentage \\
\hline Female & 122 & $\% 61,0$ \\
\hline Male & 78 & $\% 39,0$ \\
\hline Total & 200 & $\% 100$ \\
\hline
\end{tabular}

\section{2- Age:}

The data of Table No. (2) indicates that the age ranges of the respondents between levels (18_45) ranked first with a frequency of (149) and a rate of $(5.74 \%)$, while the age group from (46_65) ranked second with a frequency of (26) and a rate of $13 \%$. While the age group under 18 ranked third with a recurrence of (23) and a percentage of $(11.5 \%)$, while the age group of 66 and over got the last rank with a recurrence of (2) and a rate of $(0.1 \%)$.

This result indicates the fact that the youth group is the group most affected by this bilateral relationship, which is normal as long as this group is the age group most used and interactive on the Internet, according to many studies.

Table.2: Shows the age group of the respondents

\begin{tabular}{|c|c|c|}
\hline Age & Repetition & Percentage \\
\hline Under 18 & 23 & $11,5 \%$ \\
\hline $18-45$ & 149 & $74,5 \%$ \\
\hline $46-65$ & 26 & $13 \%$ \\
\hline $\begin{array}{c}66 \text { and } \\
\text { above }\end{array}$ & 2 & $1 \%$ \\
\hline Total & 200 & $100 \%$ \\
\hline
\end{tabular}

\section{3- According to social status:}

The marital status showed that the married got the first rank with 132 recurrences and a percentage of (66\%), while the unmarried people got (68) recurrences with a percentage of $(34 \%)$.

This is a result that can reflect the reality of the researched sample, especially if we know that the age group of shoppers are mature.

Table.3: Shows the social status category of the respondents

\begin{tabular}{|c|c|c|}
\hline $\begin{array}{c}\text { Social } \\
\text { Statue }\end{array}$ & Repetition & Percentage \\
\hline Bachelor & 68 & $34,0 \%$ \\
\hline Married & 132 & $66,0 \%$ \\
\hline Total & 200 & $100 \%$ \\
\hline
\end{tabular}

\section{Second: exposure questions:}

Q: How often do you use social media?

The respondents' answers indicated the extent of their use of social networking sites, where a category always ranked first with a frequency of (162) and a percentage (81.0\%), and the second place came in a category sometimes with a frequency of (23) and with a percentage (11.0\%), and the third place for the answer rarely came with a frequency of (15) by a percentage $(7.5 \%)$.

This indicates that these sites have become an effective and indispensable communication tool.

Table.4: Shows the use of social media sites

\begin{tabular}{|c|c|c|c|}
\hline Time & $\begin{array}{c}\text { Repetitio } \\
\mathbf{n}\end{array}$ & $\begin{array}{c}\text { Percentag } \\
\mathbf{e}\end{array}$ & Rank \\
\hline Always & 162 & $81,0 \%$ & First \\
\hline $\begin{array}{c}\text { Sometime } \\
\text { s }\end{array}$ & 23 & $11,0 \%$ & $\begin{array}{c}\text { Secon } \\
\mathrm{d}\end{array}$ \\
\hline Rarely & 15 & $7,5 \%$ & Third \\
\hline Total & 200 & $100 \%$ & \\
\hline
\end{tabular}

Q: How many hours do you use social media sites?

The respondents' answers about the number of hours they use social networking sites showed that the hours of use of (5) hours or more got the first place with a frequency (143) and a rate of $(0.71 \%)$.

While (3-5 hours) ranked the second with a frequency of (41) and at a rate of $(0.20 \%)$, while from (one to two hours) ranked the third and with a frequency of (10) and at 
a rate of $(0.5 \%)$, while (less than an hour) She got the last rank with a repetition of (6) and with a rate of $(0,3 \%)$.

It is an important result and reflects the audience's immersion in dealing and interacting with these sites, which leads to the adoption of many of their offers.

Table.5: Shows the number of hours of use

\begin{tabular}{|c|c|c|c|}
\hline Time & Frequency & Percentage & Rank \\
\hline $\begin{array}{c}\text { Less than } \\
\text { an hour }\end{array}$ & 6 & $3,0 \%$ & Fourth \\
\hline 1-2 hours & 10 & $5,0 \%$ & Third \\
\hline 3-5 hours & 41 & $20,0 \%$ & Second \\
\hline $\begin{array}{c}\text { More than } \\
5 \text { hours }\end{array}$ & 143 & $71,0 \%$ & First \\
\hline Total & 200 & $100 \%$ & \\
\hline
\end{tabular}

Q: Do you do shopping online?

The answer data of the respondents showed (Do you do shopping online) that the answer was yes on the first place with a frequency of (171) and a percentage (86.0\%), and the answer came in the second place with a frequency of (29) and with a percentage $(0.14 \%)$.

This indicates the prevalence of shopping through these sites, which constitutes a clear answer to one of the questions raised by the research.

Table.6: Shows the respondents' answers to (Do you do shopping online)

\begin{tabular}{|c|c|c|c|}
\hline Answers & Frequency & Percentage & Rank \\
\hline Yes & 171 & $86,0 \%$ & First \\
\hline No & 29 & $14,5 \%$ & Second \\
\hline Total & 200 & $100 \%$ & \\
\hline
\end{tabular}

Q: How often do you use social media sites in the shopping process?

The respondents' answers showed the extent of their use of social media sites in the shopping process, that the category always ranked first with a frequency of (107) and a percentage $(62.0 \%)$, and the second place came for a category sometimes with a frequency of (52) and with a percentage $(31.0 \%)$ and the third rank for a category rarely by repeat (12) at a rate of $(0.7 \%)$

These results indicate that social media sites are the most important pillar in the shopping process among the options offered by the Internet.

Table.7: Shows the extent to which they use social media sites in the shopping process

\begin{tabular}{|c|c|c|c|}
\hline Time & $\begin{array}{c}\text { Frequen } \\
\text { cy }\end{array}$ & $\begin{array}{c}\text { Percenta } \\
\text { ge }\end{array}$ & $\begin{array}{l}\text { Ra } \\
\text { nk }\end{array}$ \\
\hline Always & 107 & $62,0 \%$ & First \\
\hline $\begin{array}{c}\text { Sometim } \\
\text { es }\end{array}$ & 52 & $31,0 \%$ & Second \\
\hline Rarely & 12 & $7,0 \%$ & Third \\
\hline Total & 171 & $100 \%$ & \\
\hline
\end{tabular}

Q: What websites do you use the most for online shopping?

The respondents' answers about what sites they use the most for online shopping showed that Facebook ranked first with a frequency of (111) and a percentage (56.0\%), and Instagram came in second place with a frequency of (89) and a percentage (44.0\%), while YouTube did not score on any Little repetition. This applies with the results of many studies that indicate the widespread use of Facebook by the Iraqi public, and that result indicates an answer to a question posed by the research within its research problem.

Table.8: Shows the most used websites for online shopping

\begin{tabular}{|c|c|c|c|}
\hline Websites & Frequency & Percentage & Rank \\
\hline Facebook & 111 & $56,0 \%$ & First \\
\hline Instagram & 89 & $44,0 \%$ & Second \\
\hline YouTube & - & - & Third \\
\hline Total & 200 & $100 \%$ & \\
\hline
\end{tabular}

Q: What is the reason for your use of social Media sites?

The respondents' answers about the reason for their use of social media sites showed that entertainment and entertainment came in the first place with a frequency of (84) and a percentage (42.0\%), while communication with others came in second place with a frequency of (49) and at a percentage $(24.0 \%)$, and in the third place came shopping. The frequency of (42) and at a percentage of $(21.0 \%)$, and the follow-up of news came in the last place with a frequency of (25) and at a percentage of (13.0\%).

This is an important fact that must be studied to determine the importance of investing the electronic entertainment component in the shopping process. 
Table.9: Shows the reason for using social media sites

\begin{tabular}{|c|c|c|c|}
\hline Reason & Frequency & Percentage & Rank \\
\hline $\begin{array}{c}\text { Entertainment } \\
\text { and enjoyment }\end{array}$ & 84 & $42,0 \%$ & First \\
\hline Watching news & 25 & $13,0 \%$ & Fourth \\
\hline Shopping & 42 & $21,0 \%$ & Third \\
\hline $\begin{array}{c}\text { Communicating } \\
\text { with others }\end{array}$ & 49 & $24,0 \%$ & Second \\
\hline Total & 200 & $100 \%$ & \\
\hline
\end{tabular}

Q: What is your reason for resorting to social media shopping?

The respondents' answers about the reason for their resorting to shopping through social networking sites indicated that the inability to go to the market came in the first place with a frequency of (56) and at a rate of $(28.0 \%)$, while the ease of buying with a frequency of (45) and at a rate of $(23.0 \%)$ came in the second place. Speed of demand ranked third with frequency (43) and percentage $(21.0 \%)$, and the method of displaying products ranked fourth with frequency (29) and percentage (15.0\%), while the cheapest prices came in last place with frequency (27) and percentage $(13.0 \%)$.

This result indicates the logical reality of the Iraqi citizen and the Iraqi woman, which makes it difficult for some of them to access crowded markets and thus facilitates the process of buying from the Internet.

Table.10: Shows the reason for resorting to shopping through social networking sites

\begin{tabular}{|c|c|c|c|}
\hline Reason & Frequency & Percentage & Rank \\
\hline $\begin{array}{c}\text { Ease of } \\
\text { purchase }\end{array}$ & 45 & $23,0 \%$ & Second \\
\hline $\begin{array}{c}\text { order } \\
\text { speed }\end{array}$ & 43 & $21,0 \%$ & Third \\
\hline $\begin{array}{c}\text { cheap } \\
\text { prices }\end{array}$ & 27 & $13,0 \%$ & Fifth \\
\hline $\begin{array}{c}\text { Not being } \\
\text { able to go } \\
\text { to the } \\
\text { market }\end{array}$ & 56 & $28,0 \%$ & First \\
\hline $\begin{array}{c}\text { Products } \\
\text { view }\end{array}$ & 29 & $15,0 \%$ & Fourth \\
\hline Total & 200 & $100 \%$ & \\
\hline
\end{tabular}

Q: What are the most important products you prefer to buy from social media sites?

The respondents' answers to the products they prefer to buy from social networking sites showed that the clothing category came in the first place with a frequency of (74) and a percentage of $(37 \%)$, while the food category came in the second place with a frequency of (47) and a percentage of $(23.5 \%)$, and the cosmetics category ranked second. The third place, with a frequency of (25) and a rate of $(12.5 \%)$, and the household products category ranked fourth, with a frequency of (20) and a percentage (10\%), while electronic devices came in the fifth place with a frequency of (19) and a percentage (9.5\%), and it came in the sixth place Books category with a frequency of (15) and a rate of $(7.5 \%)$.

While one of the results indicated that the percentage of female shoppers was higher than males, we find that this result appears to be compatible with women's aspirations to acquire clothing that matches their desires.

Table.11: Shows the products that are preferred to be purchased from social media sites

\begin{tabular}{|c|c|c|c|}
\hline Answers & $\begin{array}{c}\text { Frequenc } \\
\mathbf{y}\end{array}$ & $\begin{array}{c}\text { Percentag } \\
\mathbf{e}\end{array}$ & Rank \\
\hline Clothes & 74 & $37 \%$ & First \\
\hline Food & 47 & $23,5 \%$ & $\begin{array}{c}\text { Secon } \\
\mathrm{d}\end{array}$ \\
\hline $\begin{array}{c}\text { Househol } \\
\text { d products }\end{array}$ & 20 & $10 \%$ & Fourth \\
\hline Books & 15 & $7,5 \%$ & Sixth \\
\hline Cosmetics & 25 & $12,5 \%$ & Third \\
\hline $\begin{array}{c}\text { Electronic } \\
\text { Devices }\end{array}$ & 19 & $9,5 \%$ & Fifth \\
\hline Total & 200 & $100 \%$ & \\
\hline
\end{tabular}

Q: How often do you do shopping on social media?

The respondents' answers indicated their rate of shopping through social media sites, where the weekly category ranked first with a frequency of (135) and $65.0 \%$, while the daily category came in second place with a frequency of (40) and at a rate of $(2.0 \%)$, and the monthly category ranked third with frequency ( 25$)$ and (12.5\%), which is a logical result, especially if we know that the material reality of the Iraqi individual may not provide the individual with the ability to shop on a daily basis. 
Table.12: Shows the rate of their shopping through social networking sites

\begin{tabular}{|c|c|c|c|}
\hline Rate & Frequency & Percentage & Rank \\
\hline Daily & 40 & $2,0 \%$ & Second \\
\hline Weekly & 135 & $65,0 \%$ & First \\
\hline Monthly & 25 & 12,0 & Third \\
\hline Total & 200 & $100 \%$ & \\
\hline
\end{tabular}

Q: Do you think that social networking sites have contributed to the increase in interest in e-marketing?

The respondents' answers indicated the extent to which they expected the contribution of communication sites to increase the interest in e-shopping, as the (I believe) category came in the first place with a frequency of (187) and a rate of $93.0 \%$, while the category (I do not believe in a repeat) came in the second place with a rate of (13) and a percentage of $6.5 \%$ ), and this is the result of a perception of the extent The respondents' awareness of the importance of social networking sites.

Table.13: Shows the extent to which they expect the contribution of communication sites to increase interest in online shopping

\begin{tabular}{|c|c|c|c|}
\hline Answers & Frequency & Percentage & Rank \\
\hline I think & 187 & $93,5 \%$ & First \\
\hline $\begin{array}{c}\text { I don't } \\
\text { think so }\end{array}$ & 13 & $6,5 \%$ & Second \\
\hline Total & 200 & $100 \%$ & \\
\hline
\end{tabular}

Q: Do you advise others to shop through social networking sites?

The respondents' answers indicated the extent to which they advised others to shop through social networking sites, where the category always ranked first with a frequency of (109) and at a rate of $54.0 \%$ ), while the category sometimes came in with a frequency of (64) and at a rate of $32.0 \%$ ), and the Never category ranked third with frequency (27) and a percentage (14.0\%), and this indicates an important result, which is that there is a possibility for this type of marketing to turn into what is called viral marketing, and this constitutes an answer to one of the research questions and objectives.
Table.14: Shows the extent to which they advise others to shop through social networking sites

\begin{tabular}{|c|c|c|c|}
\hline Answers & $\begin{array}{c}\text { Frequenc } \\
\mathbf{y}\end{array}$ & $\begin{array}{c}\text { Percentag } \\
\mathbf{e}\end{array}$ & Rank \\
\hline Always & 109 & $54,0 \%$ & First \\
\hline $\begin{array}{c}\text { Sometime } \\
\text { s }\end{array}$ & 64 & $32,0 \%$ & $\begin{array}{c}\text { Secon } \\
\mathrm{d}\end{array}$ \\
\hline Never & 27 & $14,0 \%$ & Third \\
\hline Total & 200 & $100 \%$ & \\
\hline
\end{tabular}

Q: Do you promote the goods you own through your own account?

The response data of the respondents showed that they promoted the goods that they acquired through their own account. Both ranked first with a frequency of (124) and at a rate of $62.0 \%$, and in the second place came the answer yes with a frequency of (76) and with a percentage of $(0,38 \%)$.

Table.15: Shows the respondents' promotion of the goods they acquired through their own account

\begin{tabular}{|c|c|c|c|}
\hline Answers & Frequency & Percentage & Rank \\
\hline Yes & 76 & $38,0 \%$ & Second \\
\hline No & 124 & $62,0 \%$ & First \\
\hline Total & 200 & $100 \%$ & \\
\hline
\end{tabular}

Q: Did you encounter problems with the quality of the goods you ordered?

The response data for the respondents about whether they encountered problems with the quality of the goods they requested made it clear that the category came first with a frequency of (131) and a rate of $65.0 \%$, and in the second place came the answer yes, with a frequency of (69) and with a percentage $(0.35 \%)$.

This shows that this process is going successfully and the failed operations may not seriously harm the value and idea of the entire electronic shopping process.

Table.16: Shows the respondents facing problems with the goods they purchased

\begin{tabular}{|c|c|c|c|}
\hline Answers & Frequency & Percentage & Rank \\
\hline Yes & 69 & $35,0 \%$ & Second \\
\hline No & 131 & $65,0 \%$ & First \\
\hline Total & 200 & $100 \%$ & \\
\hline
\end{tabular}


Q: What are these problems?

The respondents' answers showed what problems they face in the ordered goods, where the delayed delivery category came in the first place with a frequency of (28) and $(41.0 \%)$, while in the second place came a category that was not at the required level with a frequency of (25) and $36.0 \%$ ) and a poor quality category It ranked third with a frequency of (16) and a percentage of (23.0\%).

Table.17: Shows what are the problems facing the respondents

\begin{tabular}{|c|c|c|c|}
\hline $\begin{array}{c}\text { Answer } \\
\mathbf{s}\end{array}$ & $\begin{array}{c}\text { Frequenc } \\
\mathbf{y}\end{array}$ & $\begin{array}{c}\text { Percentag } \\
\mathbf{e}\end{array}$ & Rank \\
\hline $\begin{array}{c}\text { It was } \\
\text { not up } \\
\text { to par }\end{array}$ & 25 & $36,0 \%$ & $\begin{array}{c}\text { Secon } \\
\mathrm{d}\end{array}$ \\
\hline $\begin{array}{c}\text { Late } \\
\text { delivery }\end{array}$ & 28 & $41,0 \%$ & First \\
\hline $\begin{array}{c}\text { Poor } \\
\text { quality }\end{array}$ & 16 & $23,0 \%$ & Third \\
\hline Total & 69 & $100 \%$ & \\
\hline
\end{tabular}

\section{CONCLUSION}

In light of the results obtained from the case study and its discussion, it has been concluded the following:

1- The Baghdad public prefers to use social media sites in the shopping process to shorten time and effort due to the inability to go to the market and resort to social media sites to meet their requirements away from bearing the trouble of the road and the process of searching for the goods they need.

2- The emergence of the priority of using Facebook and Instagram sites in the shopping process, due to their wide spread in the city of Baghdad.

3- The respondents' motives for using social media sites are entertainment, leisure and leisure time.

4- It turns out that the audience of the city of Baghdad relied on social media sites in acquiring clothes, due to the large number of promotional advertisements about them.

5- Social media sites have contributed to an increase in interest in online shopping more than others

6- Friends advise their other peers to do shopping through social media sites, and it possible to conclude that this group pays great attention to the process of guiding others and advises them to shop through social media sites.

\section{RECOMMENDATIONS}

1 - It is necessary to ensure the optimal adherence to the timing of delivery of goods to customers.

2 - Establishment of free delivery companies for orders with immediate speed.

3 - The necessity for a number of scholars to show the extent to which this type of shopping has contributed to accelerating the pace of viral marketing.

\section{REFERENCES}

[1] Abdul Razzaq, R. M.(2021). The role of social networking sites in shaping political awareness(Master thesis) (K. Ethar, Trans.).University of Petra.(2013), p. 39.

[2] Al-Bayati, Y. (2021).The New Media, Freedom, Chaos and Revolutions(K. Ethar, Trans.).Emirates: Fujairah Culture and Media Authority(2014), p. 281.

[3] Al-Karkhi, A. B.(2021). The new media on TV channels $(\mathrm{K}$. Ethar, Trans.).Oman: Dar Amjad for Publishing and Distribution.(2016), p.81.

[4] Al-Mashhadani, S. (2021). Scientific Research Methodology(K. Ethar, Trans.). Oman: Dar Osama for Publishing and Distribution. (2019).

[5] Al-Tamimi, M. H. (2021). Young people's use of social networks and its relationship to television exposure (master's thesis) (K. Ethar, Trans.). University of Baghdad, (2015), p. 70.

[6] Alyan, R. M. (2021).Methods and Methods of Scientific Research(K. Ethar, Trans.).Amman: Dar Safaa for Publishing and Distribution.(2000), p. 42.

[7] Hamid, M. (2021).Media Research Methods(K. Ethar, Trans.).Cairo: World of Books.(2009), p. 225.

[8] Tabaja, Y. A. (2021).Scientific Research Methodology, Techniques and Approaches(K. Ethar, Trans.). Beirut: Dar Al-Mahaja Al-Bayda.(2011), p. 196.

[9] Sabti, O. (2021).New Media and Society(K. Ethar, Trans.).Cairo: The Arab Center for Publishing and Distribution.(2018), p. 54.

[10] Shafiq, H. (2021).New Media, Alternative Media(K. Ethar, Trans.).Dar Fikr wa Fann for Printing, Publishing and Distribution.(2010), p. 214

[11] Shaiba, S. A. (2021).Public Relations between Theory and Practice(K. Ethar, Trans.). Alexandria: Dar Al-Marefa AlJamiah.(2016), p. 42. 